\title{
Overall Layout Adjustment of Bookshelves in University Library Using the Service Marketing Concept
}

\author{
Yunxia Zhou ${ }^{1,2} \&$ Xiaozhu Zou ${ }^{1,2}$ \\ ${ }^{1}$ Institute of Scientific and Technical Information, Nanjing University of Aeronautics and Astronautics, Nanjing, \\ China \\ ${ }^{2}$ Library, Nanjing University of Aeronautics and Astronautics, Nanjing, China \\ Correspondence: Xiaozhu Zou, Institute of Scientific and Technical Information, Nanjing University of \\ Aeronautics and Astronautics, Nanjing, 210016, China. Tel: 86-25-8489-2958. E-mail: zxzlib@nuaa.edu.cn
}

Received: May 13, 2018 Accepted: June 29, 2018 Online Published: October 30, 2018

doi:10.5539/par.v7n2p11 URL: http://dx.doi.org/10.5539/par.v7n2p11

\begin{abstract}
Being a window facing readers directly, bookshelves are one of traditional facilities for university libraries to display books, journals, and documents. The layout of the bookshelves determines reader's optimal routine of borrowing and reading activities, and it thus affects their experience in the library. For university libraries, in order to provide better services, the service marketing integrated theory is applied to the service marketing of libraries. Its core idea is that service marketing should encompass such elements as product, price, place, promotion, people, process, and physical evidence. Taking the example of the library in the Ming Imperial Palace Campus of Nanjing University of Aeronautics and Astronautics, we adopt a service marketing combination strategy to guide the adjustment of the overall layout of bookshelves in the library. According to the characteristics of librarians' work in university libraries, we put forward a specific "product strategy"; "price strategy"; and "people, process, and tangible display combination strategy". By comparing and analyzing the volume of books readers borrow from the library before and after the adjustment of the bookshelves, we found that the improved layout of the bookshelves increases the library's reading volume and improve the user experience. Guided by the service marketing concept, we can effectively carry out the daily work of university libraries.
\end{abstract}

Keywords: layout of bookshelves, service marketing mix theory, university library

\section{Introduction}

Providing reading services for teachers and students is the main task of university libraries. Like other industries that aim to provide good services, university libraries need to use marketing tools (Zhu, 2001). The concept of marketing was first born in the United States, and the concept that libraries need marketing was proposed by Lutie Stearns in the academic conference held by the American Library Association in 1896. From the perspective of dialectics, practice is a basis of the theory, namely, practice has a decisive effect on theory; theory has a counter effect on practice; and scientific theory has a positive guiding influence on practice. Therefore, in carrying out daily work, university libraries cannot rely solely on experience or references to peer practices. They should recognize the importance of theoretical guidance and utilize the concept of service marketing.

Many libraries have responded to changing user expectations by consolidating service desks and providing better organization of user services (Keisling\& Sproles, 2017). The bookshelves are one of traditional facilities for university libraries to keep books, journals, and documents, which face readers directly. The layout of the bookshelves affects not only the reader's convenience of borrowing and reading books but also the style of the library. The layout of bookshelves includes the distribution of both books and overall space. In general, bookshelves are mainly distributed based on the Chinese Library Classification (CLC) and readers' borrowing rules. Based on work experience, researchers have proposed some effective booklet racking layout schemes. Library researchers have also provided some space layout design guidelines and specific implementation plans for the space layout of the bookshelves (Zhou, 2015). This article focuses on the overall layout of the bookshelves: its main purpose is not to show the design principle or improvement plan of the bookshelves' layout but to describe the concept of library services, i.e., the concept of how service marketing theory guides a librarian's daily work. 
Understanding how to use the service marketing theory to guide practical work is a relatively confusing task for library staff. This study takes the example of adjustment of the overall bookshelves' layout in the library of the Ming Palace Campus of Nanjing University of Aeronautics and Astronautics and discusses the possibility to use the service marketing combination theory to guide the daily work of university libraries. Based on this study, we aim to provide an inspiration to library professionals, as well as new ideas for the development of the library industry.

\section{Service Marketing Integrated Theory}

The service marketing integrated theory has strong applicability in service marketing. Its core idea is that service marketing has several elements, such as product, price, place, promotion, people, process, and physical evidence (Zeithaml, 2006). For different marketing objects, we can create a reasonable combination of these elements and then form a variety of combinatorial theory forms. For example, a tangible products' marketing mix consists of four elements: product, price, place, and promotion - the traditional "4P" marketing theory. Based on the traditional $4 \mathrm{P}$ theory, the service industry, providing intangible products, has added the three more elements of people, process, and tangible display, forming the " $7 \mathrm{P}$ " theory. It should be noted that a good service marketing mix strategy does not consist of too many elements. Instead, it should select the optimal service marketing integrated strategy based on specific service objects. In the space of university library, the product is the book, the price is the money, and the time is the one readers spend on books. Place means the bookshelves. Promotion links with the propaganda of the library. People are the readers. Process starts with the readers entering into the library. Display contains all the things which can be observed in the library. The service marketing theory's elements correspond with the library service contents. Utilizing the service marketing concept to bookshelves' adjustment, can make the librarians' work effective and the readers' experience better.

\section{Overall Layout Idea for Bookshelf Adjustment}

The majority of readers of university libraries are the university's teachers and students, on whom the pressure of research and study is relatively high. The main purpose of viewing books in the library is to solve the professional problems encountered in research. For teachers and students, time is an important cost of reading as well as an important factor affecting their access to library books and documents. When librarians design or adjust the layout of bookshelves, they should focus on providing readers with the greatest convenience and saving their time cost as much as possible. Based on the theory of service marketing combination, this study proposes a combination strategy for the key elements of the service marketing portfolio theory, namely, service marketing combination strategy, which is used to guide the adjustment of the overall layout of bookshelves. Figure 1 gives a block diagram of the working idea. This study focuses on this work idea and the work characteristics of university library bookshelves; then, it selects service marketing combination strategies that match those characteristics, including the "product strategy"; "price strategy"; and "people, process, and tangible display combination strategy".

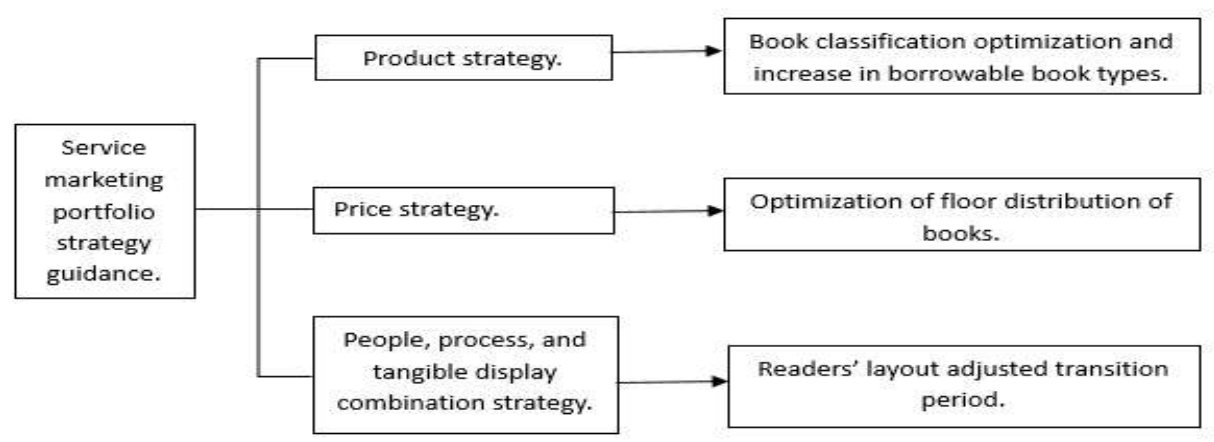

Figure 1. Working flow of the overall layout adjustment of the university library

\subsection{Product Strategy}

The products of a university library are books. The overall layout of the bookshelves should be arranged rationally around the classification of books. The readers of university libraries - teachers and students - have 
obvious professional classifications, such as natural sciences and social sciences. Therefore, the classification of college library books should be based on such professional classification. In general, there are not many books and magazines in the library, and special reading rooms can be arranged to store the shelves. There are not enough books in foreign languages for borrowing, and special books can be arranged for racking. There are two ways for readers to obtain library products: borrowing and reading. It is often believed that broadening the scope of books that can be read in the library will add readers' intention to read.

\subsection{Price Strategy}

Readers from colleges and universities generally do not incur financial costs to borrow books from the library. There are only time costs, including the time taken to borrow books, search for books in the shelves, and travel to and from different bookshelves. Therefore, librarians can save the time cost of readers in the following three ways: (1) purchase of an automatic self-machine which can help readers to borrow or return books to improve the efficiency of borrowing or returning books; (2) reasonable racking (such as classification according to the Chinese Library Classification (CLC)) and prominent positioning of bookshelves annotated with bibliographic signage; and (3) rational arrangement of the overall layout of bookshelves. We know that the bookshelves of a university library generally has the characteristics of multi-floor-distributed, and so the overall layout of the bookshelves can be optimized in book collection. In addition, the overall rational layout of the bookshelves also includes optimization of the book collection for each bookshelf.

\subsection{People, Process, and Tangible Display Combination Strategy}

For the university library, the "people" element is mainly its readers. The "process" element refers to the readers' process of receiving services in the library. The "tangible display" element refers to the service tips or propaganda posted by the library. When readers enter the library, they begin to accept the process of receiving library services. Throughout the process, readers are constantly influenced by tangible displays (such as the library's floor prompts, library presentations, and shelving prompts). Therefore, for library services, the three elements of people, process, and tangible display are linked closely. Thus, this study proposes a service marketing strategy that combines these three elements and is based on tangible display. We know that after the layout adjustment of bookshelves, readers will need a period of adaptation to the new library layout. To facilitate readers to get through this period of adaptation as soon as possible, it is necessary to use the tangible display strategy of service marketing, for instance, posting hint cards at appropriate places in the library.

\section{Implementation of the Adjustment of Bookshelf Layout in the University Library}

The bookshelves in the library of the Ming Imperial Palace Campus of Nanjing University of Aeronautics and Astronautics are mainly on the second to fourth floors. The original layout is demonstrated in Table 1, which shows that Chinese books for reading and borrowing are distributed on different floors, and both include the books in social science and natural science categories. 
Table 1. Original layout of the library of Nanjing University of Aeronautics and Astronautics

\begin{tabular}{|c|c|c|c|c|}
\hline Floor & $\begin{array}{l}\text { Names of } \\
\text { bookshelves }\end{array}$ & Book types & Resource contents & Types of loan \\
\hline \multirow[t]{2}{*}{2} & $\begin{array}{l}\text { Chinese Reading } \\
\text { Room }\end{array}$ & $\begin{array}{l}\text { Social science, } \\
\text { natural science }\end{array}$ & $\begin{array}{l}\text { Reading books, current } \\
\text { issues, and newspapers } \\
\text { in the Chinese Library } \\
\text { Classification (CLC) A- } \\
\text { X }\end{array}$ & Unavailable \\
\hline & $\begin{array}{l}\text { Aerospace Reading } \\
\text { Room }\end{array}$ & $\begin{array}{l}\text { Social science, } \\
\text { natural science }\end{array}$ & $\begin{array}{l}\text { Aerospace books, } \\
\text { conference papers, } \\
\text { industry standards, } \\
\text { dissertations, and } \\
\text { CD-ROMs }\end{array}$ & Unavailable \\
\hline \multirow[t]{2}{*}{3} & $\begin{array}{l}\text { Literature Reading } \\
\text { Room }\end{array}$ & Social science, & $\begin{array}{l}\text { in the Chinese Library } \\
\text { Classification (CLC) } \\
\text { I-novels }\end{array}$ & Unavailable \\
\hline & $\begin{array}{l}\text { Reading Room of } \\
\text { Books in Foreign } \\
\text { Languages }\end{array}$ & $\begin{array}{l}\text { Social science, } \\
\text { natural science }\end{array}$ & $\begin{array}{l}\text { All foreign language } \\
\text { books }\end{array}$ & $\begin{array}{l}\text { Partial loan (original } \\
\text { books are } \\
\text { unavailable) }\end{array}$ \\
\hline 4 & $\begin{array}{l}\text { Chinese Reading } \\
\text { Room }\end{array}$ & $\begin{array}{l}\text { Social science, } \\
\text { natural science }\end{array}$ & $\begin{array}{l}\text { All borrowed books in } \\
\text { the Chinese Library } \\
\text { Classification CLC A-Z }\end{array}$ & Available \\
\hline
\end{tabular}

The reading habits of university readers are mainly based on professional reading, and the categories of books that are of interest to readers of social and natural sciences are significantly different. If a reader refers to a specific professional book in natural science, the reader needs to visit the bookshelves on the second and fourth floors, thus being time-consuming and troublesome in searching and reviewing. On a certain floor, the reader also needs to distinguish between the classification of social science and natural science, which also increases the time for review. Due to the inconvenience in reading, some readers may reduce their frequency of reading, or it may prevent potential readers from reading in the library.

The above analysis indicates that the overall layout of the library's original book collection shows obvious irrationality, therefore, it necessitates the layout adjustment. In accordance with the working ideas presented in the previous section, the layout of the library's bookshelves was adjusted. As the volume of borrowed foreign books is much smaller than that of Chinese books, the layout of foreign books does not need to be adjusted. Thus, only the layout of Chinese books is adjusted, that is, the layout of the second and fourth floors. To reduce readers' searching time and improve the service of the library, Chinese books are divided into two categories, i.e., social science and natural science. These two types of books are concentrated on different floors. The original "Chinese Reading Room" on the second floor was renamed as "Reading Room of Social Sciences." Moreover, the natural science books were adjusted to the fourth floor to a room named "Reading Room of Natural Science." To improve readers' accessibility, the Chinese books for reading on the original second floor, which were unavailable, can be borrowed now, as well as some books in foreign languages on the third floor. In addition, in all reading rooms, the area for reading tables and chairs has increased so that more readers can have enough room for study. Table 2 shows the adjusted layout of library books. 
Table 2. Current bookshelf distribution in the library in the ming imperial palace campus of Nanjing University of Aeronautics and Astronautics

\begin{tabular}{|c|c|c|c|c|}
\hline Floor & Name of bookshelves & Book type & Resource content & Type of loan \\
\hline \multirow[t]{2}{*}{2} & $\begin{array}{l}\text { Social Science } \\
\text { Reading Room }\end{array}$ & Social science & $\begin{array}{l}\text { Books in the Chinese } \\
\text { Library Classification } \\
\text { (CLC)B, C, D, E, F, G, H, } \\
\text { I, J, K, and Z }\end{array}$ & Available \\
\hline & $\begin{array}{l}\text { Aerospace Reading } \\
\text { Room }\end{array}$ & $\begin{array}{l}\text { Social science, } \\
\text { natural science }\end{array}$ & $\begin{array}{l}\text { Aerospace books, } \\
\text { conference papers, } \\
\text { industry standards, } \\
\text { dissertations, and } \\
\text { CD-ROMs }\end{array}$ & Unavailable \\
\hline \multirow[t]{2}{*}{3} & $\begin{array}{l}\text { Chinese Newspaper } \\
\text { and Periodical } \\
\text { Reading Room }\end{array}$ & $\begin{array}{l}\text { Social science, } \\
\text { natural science }\end{array}$ & $\begin{array}{l}\text { Chinese newspapers of } \\
\text { the week and journals } \\
\text { from the current year }\end{array}$ & Unavailable \\
\hline & $\begin{array}{l}\text { Foreign Languages } \\
\text { Reading Room }\end{array}$ & $\begin{array}{l}\text { Social science, } \\
\text { natural science }\end{array}$ & $\begin{array}{l}\text { Collection of books in } \\
\text { foreign languages, } \\
\text { contemporary journals in } \\
\text { foreign language, and } \\
\text { journals in foreign } \\
\text { language }\end{array}$ & $\begin{array}{l}\text { Partial loan (original } \\
\text { books can be } \\
\text { borrowed for a short } \\
\text { period of time) }\end{array}$ \\
\hline 4 & $\begin{array}{l}\text { Natural Science } \\
\text { Reading Room }\end{array}$ & Natural science & $\begin{array}{l}\text { Chinese books in Chinese } \\
\text { Library Classification } \\
\text { (CLC) N, O, P, Q, R, T, } \\
\mathrm{U}, \mathrm{V} \text {, and X }\end{array}$ & Available \\
\hline
\end{tabular}

Based on the above adjustment program, books can be transported. Before carrying books, one should consider all details as much as possible and put a reminder on each shelf. When carrying a book, one should follow the instructions on the bookshelf to carry the book, place it, and conduct post-position identification. Hence, it is possible to ensure that the handling process is carried out in an orderly manner and does not affect the daily work of book repossession and book shelving during book adjustment. When the library has just completed its adjustment, readers entering the library will have a certain time period to adapt to the new layout of the library. To help readers adapt to the new bookshelf layout as soon as possible, we use the tactics of the "people, process, and tangible display combination strategy" based on tangible display. First, tips for the introduction of this floor of library resources will be posted on the stairs of each floor. Second, posters will be hung on the wall noticeably on each floor. For instance, the books on the second floors were for reading only, and now are available for borrowing. Posters with relevant information are thus hung at the entrance of the second floor. Finally, to change the readers' original impression, an "available" sign is posted on the side of several bookshelves. The original three-floor "Literary Reading Room" was transformed into the "Reading Room of Chinese Newspapers and Journals" (containing the weekly newspapers and contemporary journals).

\section{Influence of the Overall Layout Adjustment on Borrowing Volume}

To assess the effect of adjustments to the library's layout on the amount of borrowing, Figures 2 and 3 provide comparison data before and after the adjustment on the amount of borrowing of social science and natural science books during one semester (February to June). Figure 2 shows that the amount of borrowing of social science books increased significantly after the adjustment. In Figure 3, although the amount of borrowing of natural science books decreased in March and April after adjustment, it increased in May and June, which indicates that the overall layout of the new library makes it easy for readers to check in and increases the amount of reading. 


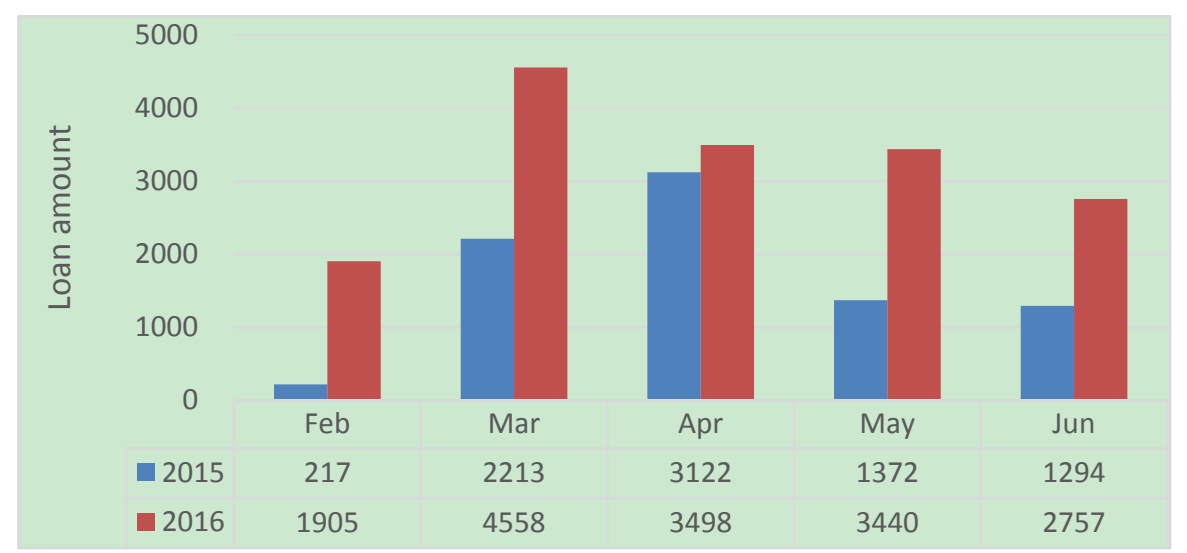

Figure 2. Comparison of the borrowed volume of social science books before and after the layout adjustment of bookshelves

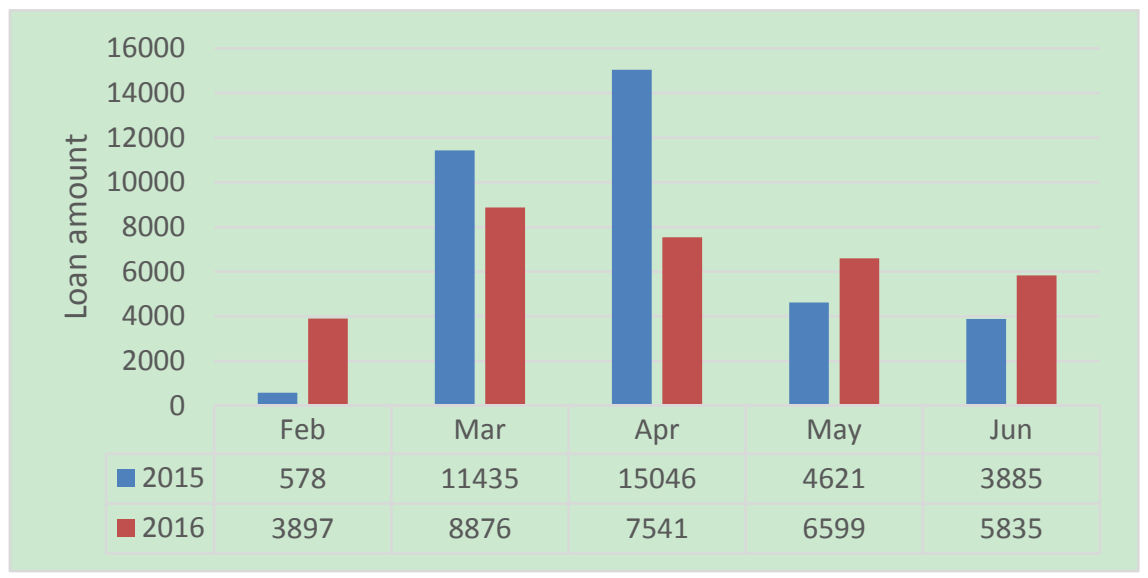

Figure 3. Comparison of the borrowed volume of natural science books before and after the layout adjustment of bookshelves

After the layout adjustment of bookshelves was accomplished, we randomly interviewed 78 readers in different time period of a day, i.e. 9:00am-10:00am, 2:00pm-3:00pm, and 7:00pm-8:00pm. The interviewees were asked to express their subjective experiences after the layout of bookshelves was adjusted. Their responses can be summarized into the conclusions that the adjusted bookshelves have more reasonable layout in terms of discipline categories of books, thus being user-friendly, and the guide signs and instructions posted on each floor are concise and informative, leading to a self-directed book-borrowing for authors without any inquire. Besides, all interviewees reported the benefit of time-saving. Hence, the interview results confirmed the satisfying impact of the layout adjustment of bookshelves in the Ming Imperial Palace Campus of Nanjing University of Aeronautics and Astronautics.

\section{Conclusions}

Taking the example of the library of the Ming Imperial Palace Campus of Nanjing University of Aeronautics and Astronautics, we adopt a service marketing combination strategy to guide the overall layout adjustment of the bookshelves in the library. By comparing and analyzing the readers' borrowing volume in the campus before and after the adjustment of the bookshelves, we found that the improved layout of bookshelves can increase the reading volume of the library. Thus, university librarians should give importance to theoretical guidance in their daily work and utilize the concept of service marketing. This concept should be implemented in every job position at a university library. The quality of a library's service can be improved via the proposed method, and this study provides a powerful support for the learning and research work of the university's teachers and students. 


\section{References}

Keisling, B., \& Sproles, C. (2017). Reviewing and Reforming Library Service Points: Lessons in Review and Planning Services, Building Layout, and Organisational Culture. Library Management, 38(8/9), 426-436. https://doi.org/10.1108/LM-02-2017-0020

Zeithaml, V. A., Bitner, M. J., \& Gremler, D. D. (2006). Services Marketing: Integrating Customer Focus Across the Firm. New York, NY: McGraw-Hill.

Zhou, Z. H. (2015, June 4). Probe into the Spatial Layout of University Library Stacks in Internet Service Environment. Sci-Tech Information Development \& Economy, 25(7), 30-32.

Zhu, Y. W. (2005, July 31). How to Extend Library Service by Making Use of Marketing. Library Development, (4), 61-63.

\section{Copyrights}

Copyright for this article is retained by the author(s), with first publication rights granted to the journal.

This is an open-access article distributed under the terms and conditions of the Creative Commons Attribution license (http://creativecommons.org/licenses/by/4.0/). 